\title{
Management of Tomato spotted wilt virus in Flue-Cured Tobacco with Acibenzolar-S-Methyl and Imidacloprid
}

A. S. Csinos and H. R. Pappu, Department of Plant Pathology, R. M. McPherson, Department of Entomology, and M. G. Stephenson, Department of Crop and Soil Sciences, University of Georgia, Coastal Plain Experiment Station, Tifton 31793

\begin{abstract}
Csinos, A. S., Pappu, H. R., McPherson, R. M., and Stephenson, M. G. 2001. Management of Tomato spotted wilt virus in flue-cured tobacco with acibenzolar- $S$-methyl and imidacloprid. Plant Dis. 85:292-296.

Tomato spotted wilt virus (TSWV) continues to be a major production constraint in flue-cured tobacco in Georgia. Pretransplant applications of acibenzolar-S-methyl (Actigard) and imidacloprid (Admire and Provado) were evaluated in field trials, singly and in combination, in four locations in 1999. Acibenzolar-S-methyl was also evaluated for its effect on growth and yield, potential phytotoxicity, and activity against tobacco blackshank incited by Phytophthora parasitica var. nicotianae. Acibenzolar-S-methyl alone and with imidacloprid significantly reduced TSWV incidence in all four locations, but the disease incidence in the imidacloprid-treated plots was lower in only one of the four sites. Applications of acibenzolar- $S$-methyl starting at 4 weeks posttransplant had no effect on TSWV incidence, size, or yield of tobacco compared with nontreated plots. Acibenzolar- $S$-methyl did not reduce blackshank in a field trial. In the greenhouse, rates of acibenzolar- $S$-methyl ranging from 0.25 to $8 \mathrm{~g}$ a.i. per 7,000 plants showed reductions in growth that did not seem to be related to rate. Pretransplant applications of acibenzolar-S-methyl were critical to the suppression of TSWV, while initial applications made posttransplant had no effect, suggesting that plants must be protected prior to introduction into the field.
\end{abstract}

Additional keywords: acquired resistance, disease control, insecticide, plant activator, systemic, thrips

Tomato spotted wilt virus (TSWV) (Family: Bunyaviridae) continues to be a serious production constraint on tobacco, peanut, tomato, and pepper in the southeastern United States. Losses in Georgia on tobacco have been severe, with an average stand loss of more than $30 \%$ and with an estimated loss of more than $\$ 28$ million in 1999 (25).

The most important vectors of TSWV found in Georgia are the thrips Frankliniella fusca (Hinds) (20), F. occidentalis (Pergande) (19), and F. bispinoa (Morgran) (24). The high population of thrips observed in Georgia and the wide host range of the virus makes management of the disease difficult (17). Efforts to manage the disease using insecticides $(12,13)$ and cultural practices have met with no success $(5,6)$. None of the commercial tobacco cultivars have demonstrated any resistance to the disease (5).

A recent study (16) has identified acibenzolar-S-methyl and imidacloprid as two

Corresponding author: A. S. Csinos

E-mail: csinos@tifton.cpes.peachnet.edu

Accepted for publication 21 November 2000.

Publication no. D-2000-1215-01R

(C) 2001 The American Phytopathological Society materials that reduce symptoms of TSWV on tobacco. Imidacloprid (Bayer Corporation, Kansas City, MO) is labeled for use against flea beetles and aphids (10) and has demonstrated activity against TSWV on tobacco and reduced Potato stem necrosis virus damage in potato (21). Acibenzolar$S$-methyl (Novartis Crop Protection, Inc., Raleigh, NC) is a plant activator that is reported to induce a plant's defense mechanism(s) $(3,11,15,18)$ and was shown to have antifungal, antibacterial, and antiviral activity across several different plant species $(1-3,7-9,14,16)$.

The objective of this study was to further outline the use rates of acibenzolar$S$-methyl on flue-cured tobacco and to determine limits of product use with regards to phytotoxicity. In addition, acibenzolar- $S$-methyl and imidacloprid were evaluated alone and in combination to determine their individual and combined activity on management of TSWV in flue-cured tobacco by using both enumeration of symptomatic plants and enzyme-linked immunosorbent assay (ELISA). In a previous study (16), acibenzolar-S-methyl showed slight activity against blackshank fungus, Phytophthora parasitica Dastur var. nicotianae (Breda de Haan) Tucker. In this study, its effect on blackshank was more closely evaluated.
MATERIALS AND METHODS

Field study 1. In 1999, field studies were conducted at four locations in Tift County, GA, on the property of the Coastal Plains Experiment Station, College of Agriculture and Environmental Sciences, University of Georgia. The locations were Blackshank farm, Blackshank nursery, Bowen farm, and Entomology site. The tests were designed to evaluate both acibenzolar- $S$-methyl (Actigard) and imidacloprid (Admire and Provado) alone and in combination for their effect on both TSWV-induced symptom expression and virus accumulation as measured by ELISA. The four locations were from as close as a few hundred meters to $15 \mathrm{~km}$ apart.

Tobacco cultivar K-326 was produced in float trays in a greenhouse (4). Treatments were applied to plants on 24 March and lightly irrigated after application to wash the test materials from the leaf surface into the root ball medium. Treatments in the greenhouse were: imidacloprid (Admire $2 \mathrm{~F})$ at $67.2 \mathrm{~g}$ a.i./7,000 plants; acibenzolar$S$-methyl (Actigard $50 \mathrm{WG}$ ) at $2 \mathrm{~g}$ a.i. per 7,000 plants; imidacloprid (Admire 2F) at $67.2 \mathrm{~g}$ a.i. per 7,000 plants plus acibenzolar- $S$-methyl at $2 \mathrm{~g}$ a.i. per 7,000 plants; and a nontreated control. Applications were made with hand-held mechanical misters. Plants were transplanted into field plots in the four locations 7 to 9 days posttreatment, depending on location. Plants were transplanted at the Entomology site on 31 March, at the Blackshank nursery and Bowen farm on 1 April, and at the Blackshank farm on 2 April 1999. Plots at the Blackshank farm and Blackshank nursery sites consisted of a single row of plants $10.7 \mathrm{~m}$ long with $1.2 \mathrm{~m}$ between rows and $0.45 \mathrm{~m}$ between plants in the row. The Entomology and the Bowen farm plots consisted of two rows each with the same plot size dimensions. Each treatment was randomized in a complete block design and replicated four times. Field postplant treatments were: imidacloprid (Provado 1.6 F) at $21.5 \mathrm{~g}$ a.i. per 7,000 plants for treatments receiving float house applications of imidacloprid; acibenzolar- $S$-methyl at $25 \mathrm{~g}$ a.i. per 7,000 plants for treatments receiving float house treatments of acibenzolar$S$-methyl; both test materials for treatments receiving both materials in the float house; and a nontreated control. Applications were made $1,2,3$, and 4 weeks posttransplant for all locations except the Entomol- 
ogy site, which received only 1,2 , and 3 week posttransplant sprays. Applications were made with a backpack $\mathrm{CO}^{2}$ powered sprayer employing three TX-12 tips at 45 psi in a $45-\mathrm{cm}$ band in 187 to 262 1iters of water per hectare, depending on size of plants and locations. Tobacco plant heights in centimeters were measured for 10 plants in each plot from the soil surface to the tip of the tallest leaf 7 weeks posttransplanting for each location.

The numbers of plants expressing TSWV-induced symptoms in a consecutive, predetermined 10-plant array was recorded every 2 weeks and was reported as a cumulative percentage. Single leaf samples from these same plants were taken every 2 weeks and analyzed using a commercially available ELISA kit (Agdia Inc., Elkhart, IN) to determine TSWV infection. Since destructive methods were used to sample plants in plots for ELISA determination, yield data were not collected for field study 1 (four locations). Production practices, as recommended by the University of Georgia Cooperative Extension Service, were used for all locations (4). Data were analyzed by ANOVA, and area under the disease progress curve (AUDPC) was calculated for each treatment in each of the four tests and compared for significant differences using Waller's $k$-ratio $t$ test $(22,23)$.

Field study 2. Another field trial was initiated at the Blackshank nursery location in an area devoid of $P$. parasitica var. nicotianae to evaluate the effect of posttransplant applications of acibenzolar- $S$ methyl on incidence of TSWV, phytotoxicity, and yield. Tobacco transplants were produced as described previously (3) and transplanted on 1 April.

Treatments were acibenzolar-S-methyl at $8.4 \mathrm{~g}$ a.i./ha, $16.8 \mathrm{~g}$ a.i./ha, $33.6 \mathrm{~g}$ a.i./ha, and $67.3 \mathrm{~g}$ a.i./ha (Table 1). Applications were made on 3 May, 11 May, 19 May, and 26 May. Mefenoxam (Ridomil Gold 4EC) at $1.68 \mathrm{~kg}$ a.i./ha applied as preplant incorporated application on 25 March acted as a standard, while a nontreated plot acted as a control. Plots were two rows $10.7 \mathrm{~m}$ long and $1.2 \mathrm{~m}$ between rows, with a $0.45-\mathrm{m}$ space between plants randomized and replicated four times. Spray application were made with a back-pack $\mathrm{CO}_{2}$ operated sprayer as described previously. Production practices followed Georgia Cooperative Extension Service recommendations (4). The numbers of plants expressing TSWVinduced symptoms were recorded every 2 weeks, and a total percent infected plants was reported. Plant heights were measured on 25 May by measuring from the soil line to the tip of the tallest leaf in centimeters. Yields were taken by harvesting leaves on 8 July, 12 July, and 4 August and converting green weight to dry weight in kilograms per hectare using a 0.20 factor (16). Data were analyzed by ANOVA or GLM procedures of SAS (SAS Institute, Cary,
NC). Significant differences were determined by Duncan's multiple range test at $P$ $=0.05(22,23)$.

Field study 3. A third field trial was initiated to determine the activity of acibenzolar- $S$-methyl on tobacco blackshank incited by $P$. parasitica var. nicotianae and tomato spotted wilt incited by TSWV when applied in the soil preplant incorporated or as a postplant foliar spray. Treatments were: mefenoxam (Ridomil Gold 4E or Ultra Flourish 2E) applied at $560 \mathrm{~g}$ a.i./ha preplant incorporated (PPI) plus 280 $\mathrm{g}$ a.i./ha at first cultivation (1st cult) and $280 \mathrm{~g}$ a.i./ha layby; mefenoxam 4E at 560 plus 280 and $280 \mathrm{~g}$ a.i./ha (PPI, 1st cult, and layby) plus acibenzolar- $S$-methyl at 70 plus 35 and $35 \mathrm{~g}$ a.i./ha (PPI, 1st cult, and layby); mefenoxam $4 \mathrm{E}$ at $560 \mathrm{~g}$ a.i./ha (PPI) plus acibenzolar- $S$-methyl at 35,35 , and $70 \mathrm{~g}$ a.i./ha (PPI, 1st cult, and layby); acibenzolar- $S$-methyl at 35,35 , and $70 \mathrm{~g}$ a.i./ha (1st cult, 2 nd cult, and layby); and a nontreated control (Table 2). Preplant soil incorporated treatments were applied with a tractor-powered rototiller on 30 March. The tobacco cultivar K-326 was trans-

Table 1. Incidence of Tomato spotted wilt virus (TSWV), plant height, and yield of tobacco treated with acibenzolar- $S$-methyl

\begin{tabular}{llccc}
\hline Treatment and rate/ha & Application & $\begin{array}{c}\text { TSWV } \\
(\mathbf{\%})\end{array}$ & $\begin{array}{c}\text { Height }^{\mathbf{x}} \\
(\mathbf{c m})\end{array}$ & $\begin{array}{c}\text { Yield }^{\mathbf{y}} \\
(\mathbf{k g} / \mathbf{h a})\end{array}$ \\
\hline Acibenzolar- $S$-methyl, 8.4 g a.i. & 4 weekly sprays & $39^{\mathrm{z}}$ & 58 & 2,746 \\
Acibenzolar-S-methyl, 16.8 g a.i. & 4 weekly sprays & 36 & 57 & 2,885 \\
Acibenzolar- $S$-methyl, 33.6 g a.i. & 4 weekly sprays & 44 & 58 & 2,906 \\
Acibenzolar- $S$-methyl, 67.3 g a.i. & 4 weekly sprays & 42 & 62 & 2,442 \\
Acibenzolar- $S$-methyl, 1.68 kg a.i. & Preplant incorporate & 46 & 61 & 2,764 \\
Nontreated control & None & 40 & 64 & 2,906 \\
\hline
\end{tabular}

${ }^{\mathrm{v}}$ Tobacco 'K-326' was transplanted on 1 April and sprayed on 3 May, 11 May, 19 May, and 26 May. Preplant incorporated applications were made on 25 March.

${ }^{\text {w}}$ Cumulative percent TSWV symptomatic plants, based on counts made every 2 weeks starting 14 April and ending 28 July.

${ }^{x}$ Height measurements were made on 10 plants per plot by measuring from the soil line to the tip of the tallest leaf on 25 May.

y Leaves were harvested 8 July, 12 July, and 4 August, and green weight was converted to dry weight by using a 0.20 conversion factor.

${ }^{\mathrm{z}}$ None of the parameters were significantly different according to Duncan's multiple range test, $P=$ 0.05 .

Table 2. The effect of foliar sprays of acibenzolar-S-methyl on tobacco height and root length

\begin{tabular}{lccc}
\hline $\begin{array}{c}\text { Acibenzolar-S-methyl } \\
\text { (g a.i./7,000 plants) }\end{array}$ & $\begin{array}{c}\text { Timing of applica- } \\
\text { tion }^{\mathbf{w}}\end{array}$ & $\begin{array}{c}\text { Plant height } \\
(\mathbf{c m})^{\mathbf{x}}\end{array}$ & $\begin{array}{c}\text { Root length } \\
(\mathbf{c m})^{\mathbf{y}}\end{array}$ \\
\hline 8 & 1 & $16.3 \mathrm{ab}^{\mathrm{z}}$ & $26.2 \mathrm{ab}$ \\
4 & 1 & $16.9 \mathrm{ab}$ & $22.5 \mathrm{ab}$ \\
2 & 1 & $15.9 \mathrm{abc}$ & $21.2 \mathrm{ab}$ \\
1 & 1 & $15.2 \mathrm{bc}$ & $18.8 \mathrm{~b}$ \\
0.5 & 1 & $16.6 \mathrm{ab}$ & $22.1 \mathrm{ab}$ \\
0.25 & 1 & $18.1 \mathrm{ab}$ & $29.8 \mathrm{a}$ \\
1 & $1+1$ & $16.3 \mathrm{ab}$ & $20.9 \mathrm{ab}$ \\
0.5 & $1+1$ & $17.3 \mathrm{a}$ & $23.6 \mathrm{ab}$ \\
0.5 & $1+1+1$ & $14.3 \mathrm{c}$ & $20.5 \mathrm{ab}$ \\
0 & N/A & $17.7 \mathrm{a}$ & $21.7 \mathrm{ab}$ \\
\hline
\end{tabular}

${ }^{\text {w}}$ Tobacco 'K-326' was seeded on 19 September and treated on 21 October, using mechanical misters. Application timings were: 1 was a single application. $1+1$ was once plus 1 week later; and $1+1+1$ was once plus again 1 week and 2 weeks later.

${ }^{\mathrm{x}}$ Plant heights, from the soil line to the tallest leaf, were measured on 11 November for nine plants in each treatment.

${ }^{y}$ Root lengths were measured on 11 November for nine plants in each treatment.

${ }^{\mathrm{z}}$ Means followed by the same letter are not significantly different $(P=0.5)$ according to Duncan's multiple range test. 
were calibrated to deliver the exact amount of calculated material per plant using mechanical misters. Each treatment had nine plants, and height and root length of each plant was measured in centimeters on 11 November. Data were analyzed as described previously.

\section{RESULTS}

Field study 1. TSWV incidence in nontreated controls ranged from 33 to $41 \%$ across the four locations (Fig. 1). The lowest level of disease generally occurred in plots treated with a combination of imidacloprid and acibenzolar-S-methyl. The AUDPC was greater for the nontreated control treatment than for treatments consisting of acibenzolar- $S$-methyl alone and in combination with imidacloprid for all four locations. The AUDPC for imidacloprid-treated plots was significantly less than for the nontreated control treatment in only one of the four locations (Fig. 1). The AUDPC for the acibenzolar- $S$-methyl treatment was less than the AUDPC for imidacloprid-treated plots in only one of the four locations. Although the AUDPC for the combination of acibenzolar- $S$ methyl and imidacloprid was consistently lower than for acibenzolar-S-methyl alone, they were not significantly different from each other in any of the four locations.

In most cases, AUDPC for ELISApositive samples mirrored disease levels noted for symptomatic plants (Fig. 2), although they were generally higher than the number of symptomatic plants. In the nontreated controls at the Entomology and Bowen sites, cumulative ELISA percentages were 219 and $200 \%$ higher, respectively, than cumulative numbers of symptomatic plants at 160 days (Fig. 1).

Field study 2. Although incidence of TSWV was relatively high in this test, ranging from 36 to $46 \%$ incidence, many of the infected plants did not die and at least some yield was recovered from infected plants. No rate of acibenzolar- $S$-methyl applied starting at 5 weeks postplant influenced the incidence of TSWV, size of tobacco, or the yield of tobacco when compared with the nontreated control (Table 1).

Field study 3. Incidence of tobacco blackshank and TSWV ranged from 0 to
$33 \%$ and 23 to $40 \%$, respectively (data not shown). All plots that received mefenoxam had zero blackshank, but plots treated with only acibenzolar- $S$-methyl in any of the pre- or postplant applications had tobacco blackshank levels similar to the nontreated control. Acibenzolar-S-methyl reduced incidence of TSWV in only two of four treatments when compared with mefenoxam-treated plots but did not significantly reduce TSWV incidence over the nontreated control. Only three of the four plots receiving multiple applications of mefenoxam (560 g a.i. PPI, $280 \mathrm{~g}$ a.i. $1 \mathrm{st}$ or 2 nd cult, and $280 \mathrm{~g}$ a.i. layby) had significantly greater yield than the nontreated control.

Greenhouse. A greenhouse trial was initiated to evaluate any phytotoxic effects from application of acibenzolar- $S$-methyl on tobacco seedlings (Table 2). Only the 1 $\mathrm{g}$ a.i. per 7,000 plants treatment applied once and the $0.5 \mathrm{~g}$ a.i. per 7,000 plants treatment applied three times resulted in significantly shorter plants. None of the treatments affected root growth compared with the nontreated controls; however,

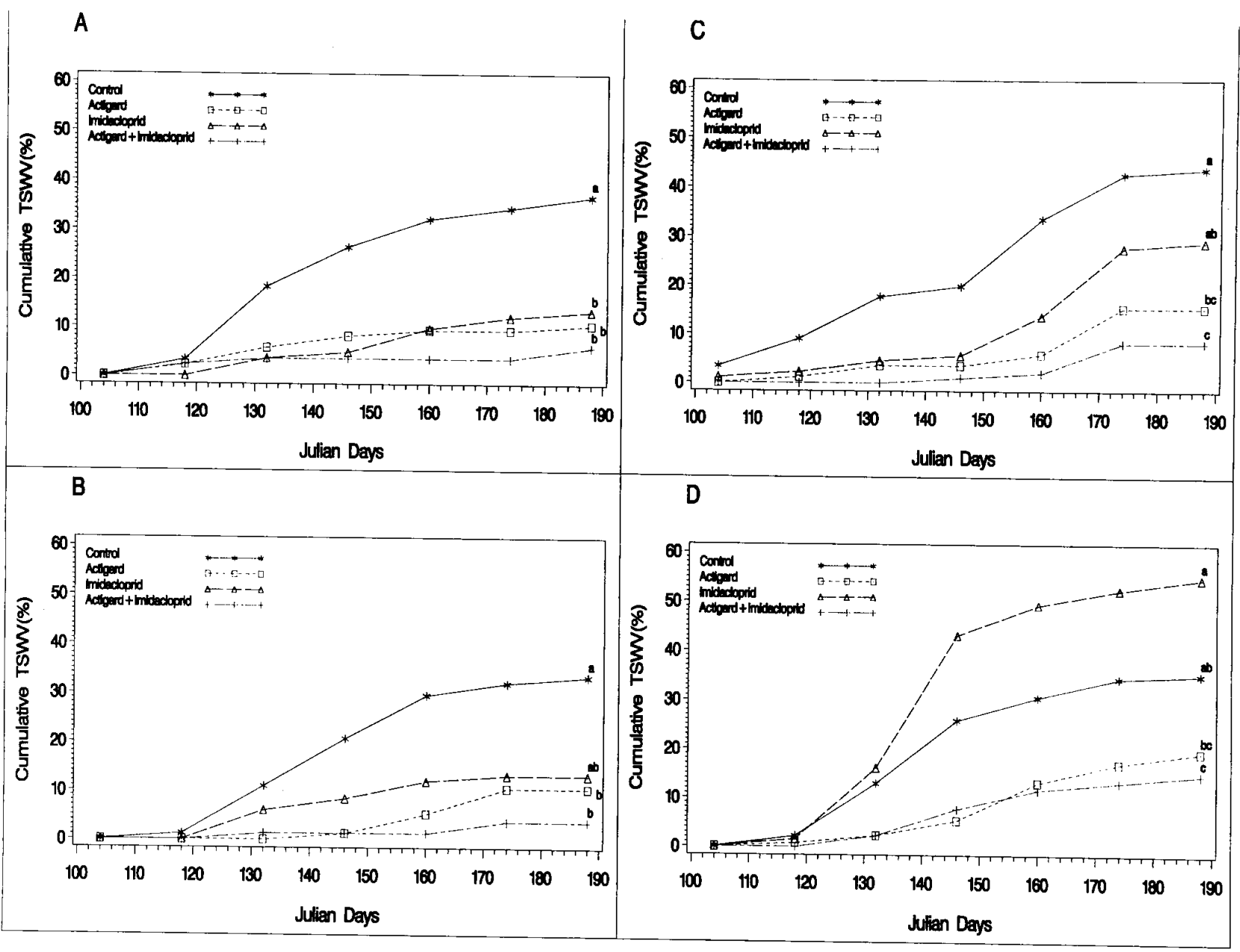

Fig. 1. Area under the disease progress curve (AUDPC) for cumulative symptomatic Tomato spotted wilt virus (TSWV) tobacco treated with acibenzolar$S$-methyl (Actigard), imidacloprid (Admire or Provado), a combination of acibenzolar-S-methyl plus imidacloprid, and a nontreated control. The four locations are A, Blackshank farm; B, Blackshank nursery; C, Entomology site; and D, Bowen farm. Curves (areas) followed by the same letter(s) are not significantly different in area from each other, $P=0.05$. 
plants treated with $1.0 \mathrm{~g}$ a.i. per 7,000 plants of acibenzolar- $S$-methyl had shorter roots than plants treated with $0.25 \mathrm{~g}$ a.i. per 7,000 plants.

\section{DISCUSSION}

TSWV incidence in 1999 was the highest encountered to date in flue-cured tobacco in Georgia. Symptoms were observed from just after transplanting until harvest, with the nontreated plots averaging over 30\% incidence. Exponential increases in both incidence of symptoms and ELISA-positive samples occurred between 120 and 160 Julian days and between 120 to 145 Julian days, respectively. These dates also closely approximate tobacco's rapid growth stage from approximately 30 $\mathrm{cm}$ to flowering. After those dates, both incidence and number of new ELISApositive samples decreased. We suggest that the infection process occurs relatively early in the season. One hundred and sixty Julian days represents the flowering stage of tobacco in the Georgia growing belt, and very few new infections are seen after flowers are removed from tobacco plants.
Greenhouse application of $8 \mathrm{~g}$ a.i. per 7,000 plants did not cause growth reduction up to 21 days posttreatment. However, these plants were not stressed during the test, as they would be if they were subjected to transplant shock or harsh environmental conditions in the field. We found it odd that a $1 \mathrm{~g}$ a.i. application caused stunting, but in the same test $8 \mathrm{~g}$ a.i. did not. This would suggest that the physiological status of individual transplants in a population may determine its phytotoxic response.

In a trial where acibenzolar- $S$-methyl was applied as four weekly sprays starting 4 weeks posttransplant (Table 1), no significant differences occurred in incidence of TSWV, height of tobacco plants, or yield of tobacco from the plots. This occurred even though up to four times the recommended manufacturer's rate of acibenzolar-S-methyl was applied. In a previous study (16), early applications made prior to transplanting in the float house at $25 \mathrm{~g}$ a.i. per 7,000 plants caused significant phytotoxicity and resulted in reduced early plant growth and some mortality. Estab- lished, rapidly growing plants were not adversely affected by acibenzolar- $S$ methyl. In this study, seedlings were treated with $2 \mathrm{~g}$ a.i. of acibenzolar- $S$ methyl prior to transplanting, and no reduction in growth occurred (data not shown). However, in a few of the studies conducted in Georgia on grower's fields in 2000 , early growth reductions have occurred (P. F. Bertrand, personal communication). Studies on this unpredictable growth reduction will be required to elucidate the problem.

Applications of acibenzolar- $S$-methyl made preplant incorporated in the field or first cultivation (11 days postplant) did not reduce incidence of TSWV. Greenhouse applications prior to transplanting provided protection against TSWV, whereas applications made in the field starting 4 weeks posttransplant did not provide protection against TSWV. These data lead us to suggest that there is a very small window of opportunity to protect tobacco against TSWV symptom expression. Since the reported activity of acibenzolar-S-methyl is to activate the plant's natural defense

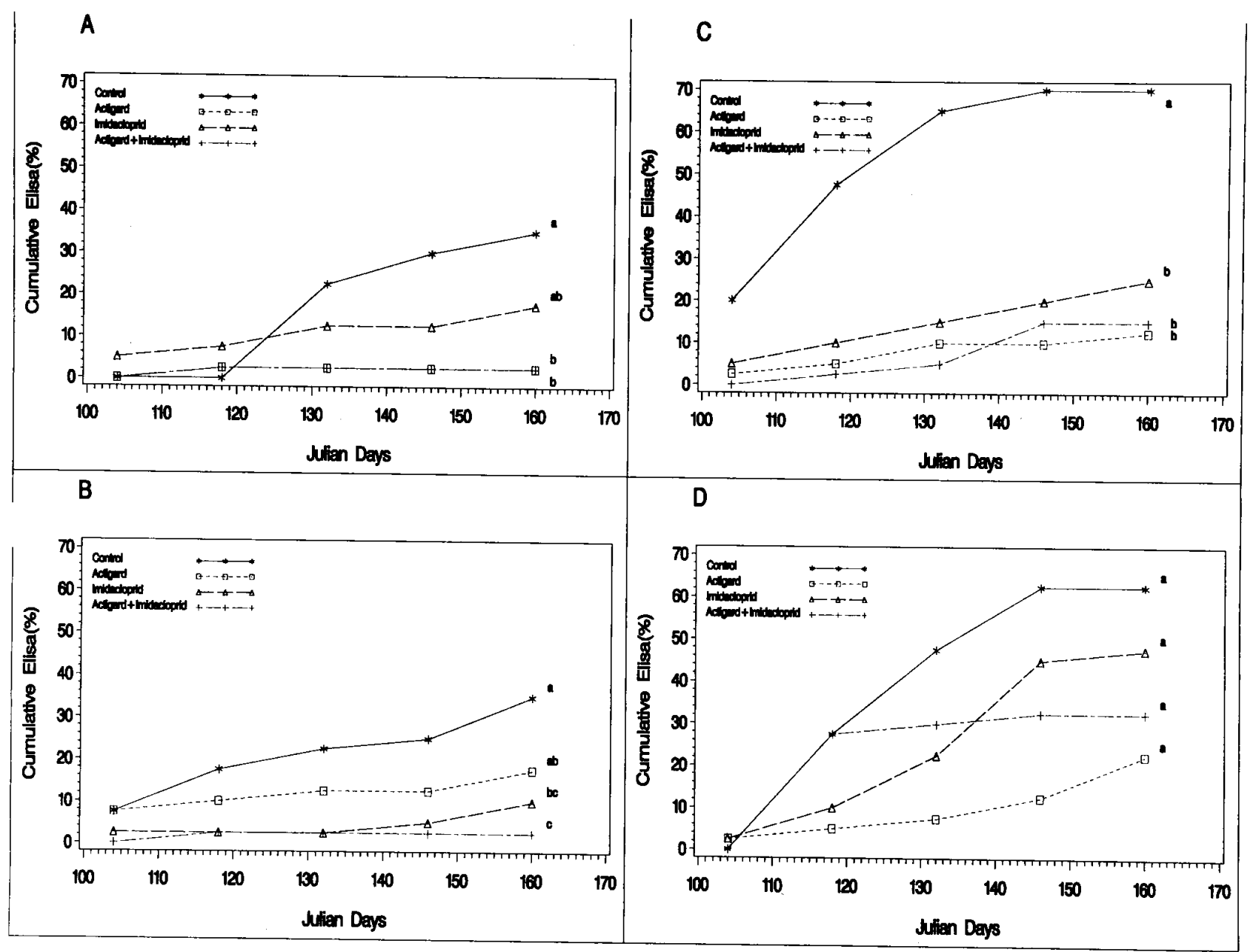

Fig. 2. Area under the disease progress curve (AUDPC) for cumulative enzyme-linked immunosorbent assay (ELISA) positive samples. Treatments were acibenzolar-S-methyl (Actigard), imidacloprid (Admire or Provado), a combination of acibenzolar- $S$-methyl plus imidacloprid, and a nontreated control. The four locations are A, Blackshank farm; B, Blackshank nursery; C, Entomology site; and D, Bowen farm. Curves (areas) followed by the same letter(s) are not significantly different in area from each other, $P=0.05$. 
mechanism $(15,17)$, we have yet to determine the optimum time required for this to occur. Plants that are actively growing under ideal growth conditions such as those found in float houses may absorb the activator more quickly or assimilate it into their metabolism more readily than plants undergoing transplant shock in the field. Since symptoms of TSWV infection occurred very soon after transplanting, and plants were symptomless and tested negative for TSWV by ELISA prior to transplanting, we suspect that infection can occur within days of the transplanting event. This would make it imperative that acibenzolar-S-methyl be applied in sufficient time prior to transplanting to activate the plant's defense system. The exact timing of that scenario is unknown. However, in these tests applications, 7 to 9 days prior to transplanting appeared to have been sufficient to provide protection from TSWV. The work conducted thus far leads us to suggest that pretransplanting applications of acibenzolar- $S$-methyl are more important than field applications either as soil-applied preplant treatments or as foliar postplant treatments.

An earlier study on tobacco (16) also indicated that ELISA-positive samples were much higher than the observed number of symptomatic plants. These results suggest that ELISA accurately identifies infection but not every infection may result in a symptomatic plant. In a study in 1998, ELISA-positive sampling and symptomatic plants in nontreated controls ranged from 20 to $65 \%$ and 3 to $20 \%$, respectively (15). This suggests that three to five times more infections are present than the number of symptomatic plants in a field. Factors such as physiological state of the plant, environmental conditions, or virus titer may influence the development of a symptomatic plant and may account for fluctuating years of low and high incidence of disease.

Although acibenzolar- $S$-methyl is a plant defense activator (15) and has been shown to reduce incidence of bacterial, fungal, and viral diseases $(1-3,7-9,14,16)$, it does not appear to affect a general activation of host plant defense mechanism but may be pathogen specific. Acibenzolar- $S$-methyl application did not result in reduced infection by $P$. parasitica var. nicotianae. In greenhouse experiments (not shown), acibenzolar-S-methyl showed only slight reduction in infection when plants were artificially inoculated, and only at rates that were phytotoxic to tobacco seedlings. TSWV is significantly reduced by acibenzolar-S-methyl, whereas $P$. parasitica var. nicotianae field infections were not reduced in flue-cured tobacco. Although the activation of the plant defense mechanism for TSWV in tobacco appears to be a reliable means for TSWV reduction, the activation must be evaluated for each hostpathogen combination.

Studies are currently underway to evaluate the levels of pathogenesis related (PR) proteins produced by specific acibenzolar$S$-methyl application scenarios. We have yet to determine both rate and frequency of acibenzolar- $S$-methyl application required to maximize and maintain PR protein production for protection against TSWV under Georgia growing conditions and simultaneously avoid early growth reduction.

\section{ACKNOWLEDGMENTS}

We thank the Philip Morris Tobacco Company USA, the Georgia Agricultural Commodity Commission for Tobacco, Bayer Corporation, and Novartis Crop Protection for financial support. The excellent technical assistance of Bert Crow, Lisa Gibson, Jimmy Laska, Kippy Lewis, Lewis Mullis, and Cindy LaHue is gratefully acknowledged.

\section{LITERATURE CITED}

1. Benhamou, N., and Belanger, R. R. 1998. Induction of systemic resistance to Pythium damping-off in cucumber plants by benzothiadiazole: Ultrastructure and cytochemistry of the host response. Plant J. 14:13-21.

2. Campbell, H. L., and Wilson, M. 1999. Evaluation of Actigard (CGA-245704) for the control of bacterial spot of peach. (Abstr.) Phytopathology 89:S11.

3. Cole, D. L. 1999. The efficacy of acibenzolar$S$-methyl, and inducer of systemic acquired resistance, against bacterial and fungal diseases of tobacco. Crop Prot. 18:267-273.

4. Cooperative Extension Service. 1999. Georgia Tobacco Grower's Guide. J. M. Moore, ed. University of Georgia, Cooperative Extension Service Publ. CSS98-9. Tifton, GA

5. Culbreath, A. K., Csinos, A. S., Bertrand, P. F., and Demski, J. W. 1991. Tomato spotted wilt virus epidemic in flue-cured tobacco in Georgia. Plant Dis. 75:483-485.

6. Culbreath, A. K., Todd, J. W., Brown, S. L., Baldwin, J. A., and Pappu, H. R. 1999. A genetic and cultural package for management of tomato spotted wilt virus in peanuts. Biol. Cultural Tests 14:1-8.

7. Gorlach, J., Volrath, S., Knauf-Beiter, G., Hengy, G., Beckhove, U., Kogel, K. H., Oosterdorp, M., Stuad, T., Ward, E., Kessman, H., and Ryals, J. 1996. Benzothiadiazle, a novel class of inducers of systemic acquired resistance, activates gene expression and disease resistance in wheat. Plant Cell 8:629.

8. Ishii, H., Tomita, Y., Horio, T., Narusaka, Y., Nakazawa, Y., Nishimura, K., and Iwamoto, S. 1999. Induced resistance of acibenzolar-Smethyl (CGA 245704) to cucumber and Japanese pear diseases. Eur. J. Plant Pathol. 105:77-85

9. Jensen, B. D., Latunde-Dada, O., Hudson, D., and Lucas, J. A. 1998. Protection of Brassica seedlings against downy mildew and damping-off by seed treatment with CGA-245704, an activator of systemic acquired resistance. Pestic. Sci. 52:63-69.

10. Jones, D. C., and McPherson, R. M. 1999. Tobacco field insect control. Univ. Georgia
College Agric. Environ. Sci. 1999 Georgia Pest Control Handb. Spec. Bull. 28:126-127.

11. Lawton, K. A., Friedrich, L., Hunt, M., Weymann, K., Delaney, T., Kessmann, H., Stuab, T., and Ryals, J. 1996. Benzothiadiazole induces disease resistance in Arabidopsis by activation of the systemic acquired resistance signal transduction pathways. Plant J. 10:7182.

12. McPherson, R. M., Beshear, R. J., and Culbreath, A. K. 1992. Seasonal abundance of thrips (Thysanoptera: Suborders Terebrantia and Tubulifera) in Georgia flue-cured tobacco and impact of management practices on the incidence of tomato spotted wilt virus. J. Entomol. Sci. 27:257-268.

13. McPherson, R. M., Pappu, H. R., and Jones, D. C. 1999. Occurrence of five thrips species on flue-cured tobacco and impact on spotted wilt disease incidence in Georgia. Plant Dis. 83:765-767.

14. Morris, S. W., Vernooij, B., Titatarn, S., Starrett, M., Thoms, S., Wiltse, C. C., Frederiksen, R. A., Bhandhufalck, A., Hulbert, S., and Uknes, S. 1998. Induced resistance responses in maize. Mol. Plant-Microbe Interact. 11:643-658.

15. Novartis Crop Protection. 1999. Actigard, a new and novel plant health product for protection against diseases of agronomic, vegetable and tree crops. Novartis Crop Protection Tech. Bull.

16. Pappu, H. R., Csinos, A. S., McPherson, R. M., Jones, D. C., and Stephenson, M. G. 2000. Effect of acibenzolar-S-methyl and imidacloprid on suppression of tomato spotted wilt Tospovirus in flue-cured tobacco. Crop Prot. 19:349-354.

17. Riley, D. G., and Pappu, H. R. 2000. Evaluation of tactics for management of thrips vectored Tomato spotted wilt virus in tomato. Plant Dis. 84:847-852.

18. Ruess, W., Mueller, K., Kanuf-Beiter, G., Kunz, W., and Staub, T. 1996. Plant activator CGA 245704: An innovative approach for disease control in cereals and tobacco. Pages 53-60 in: Proc. Brighton Crop Prot. Conf. Pest Dis.

19. Sakimura, K. 1962. Frankliniella occidentalis (Thysanoptera: Thripidae), a vector of the tomato spotted wilt virus, with special reference to the color forms. Ann. Entomol. Soc. Am. 55:387-389.

20. Sakimura, K. 1963. Frankliniella fusca, and additional vector for the tomato spotted wilt virus, with notes on Thrips tabaci, another vector. Phytopathology 53:412-415.

21. Singh, R. B., Srivastava, K. K., and Paul Khurana, S. M. 1999. Seed tuber treatment with imidacloprid protects potato crop from vector spread of the stem necrosis tospovirus. Page 52 in: Proc. Annu. Meeting Indian Phytopathol. Soc., 51st, Lucknow, India.

22. Steel, R. C. D., and Torrie, J. H. 1960. Principles and Procedures of Statistics. McGrawHill, New York.

23. Waller, R. A., and Duncan, D. B. 1969. A Bayes rule for symmetric multiple comparison problem. J. Am. Statist. Assoc. 64:14841499.

24. Webb, S. E., Kok-Yokomi, M. L., and Tsai, J. H. 1997. Evaluation of Frankliniella bispinosa as a potential vector of tomato spotted wilt virus. Phytopathology 87:S102.

25. Williams-Woodward, J. L. 1999. 1998 Georgia plant disease loss estimates. University of Georgia Crop Ext. Serv. Publ. Path 99-02. 